\title{
The first records of the tribe Lechriini (Diptera: Limoniidae) in Japan, with descriptions of three new species
}

\section{Первая находка трибы Lechriini (Diptera: Limoniidae) в Японии с описанием трёх новых видов}

\author{
D. Kato*, T. Tachi** \\ A. Като*, Т. Тачи** \\ * Echigo-Matsunoyama Museum of Natural Sicences, «Kyororo», 1712-2 Matsunoyama, Tôkamachi 942-1411 Japan. E-mail: \\ hehemanpuldoa.d4@gmail.com. \\ * Музей природы Этиго-Мацунояма, Кьороро, 1712-2 Мацунояма, Токамати 942-1411 Япония. \\ ** Biosystematics Laboratory, Faculty of Social and Cultural Studies, Kyushu University, 744 Motooka, Fukuoka 819-0395 Japan. \\ ** Лаборатория биосистематики, Факультет социальных и культурных исследований, Университет Кюсю, 744 Мотоока, \\ Фукуока 819-0395 Япония.
}

Key words: Ceratolimnobia, Japan, Lechria, Limoniidae, Trichoneura, Xipholimnobia.

ключевые слова: Ceratolimnobia, Япония, Lechria, Limoniidae, Trichoneura, Xipholimnobia.

\begin{abstract}
The tribe Lechriini is recorded from Japan for the first time. Three new species of the tribe, Lechria yamauchii Kato sp.n., Trichoneura (Ceratolimnobia) ishigakiensis Kato sp.n., and T. (Xipholimnobia) japonica Kato sp.n. are described. This is the first record of Lechria from the Palaearctic region. Images of their external appearance and wings, and drawings of their male terminalia are shown. Morphological characters of Lechriini are noted, and a key to the Japanese species is provided.
\end{abstract}

Pезюме. В статье приводится первое указание трибы Lechriini для Японии. Описываются три новых вида: Lechria yamauchii sp.n., Trichoneura (Ceratolimnobia) ishigakiensis sp.n., и T. (Xipholimnobia) japonica sp.n. Это первая находка рода Lechria в Палеарктике. Приведены изображения общего вида, а также рисунки терминалий самцов. Составлен определитель японских видов. Обсуждаются морфологические признаки трибы Lechriini.

\section{Introduction}

Lechriini are one of the tribes in the subfamily Limoniinae and comprise two genera, Lechria Skuse, 1890, and Trichoneura Loew, 1850. Lechria includes 18 species from the Oriental and Australian / Oceanian Regions [Oosterbroek, 2020]. Trichoneura includes three subgenera with 10 species: Ceratolimnobia Alexander, 1920a (one species from the Afrotropical Region); Trichoneura (one species from the Australian / Oceanian Regions); Xipholimnobia Alexander, 1921 (eight species from the Oriental and Afrotropical Regions) [Oosterbroek, 2020]. Five fossil species of the subgenus Trichoneura are known [Kania, 2015].

Lechria was previously placed in different subfamilies or families: Chioneinae [Skuse, 1890 (section Eriopterina); Brunetti, 1911, 1918 (section Eriopterini)]; Trichoceridae [de Meijere, 1911]; Limnophilinae [Alex- ander, 1920b, c (tribe Limnophilini)]. Alexander [1927] established the tribe Lechriini for the genus in Limoniinae according to the one-family concept under Tipuloidea without mentions on the morphological definition of the tribe. Trichoneura was included in Lechriini, and two genera, Ceratolimnobia and Xipholimnobia were treated as subgenera of Trichoneura [Alexander, 1934]. Tjeder [1981] observed some morphological similarities between Toxorhina (Ceratocheillus) Wesche, 1910 (Toxorrhinini in the paper, recently placed in Limoniinae) and Trichoneura (Ceratolimnobia). Stary [1992] treated Lechria and Xipholimnobia (as genus) in the four-family concept for the first time and included them in the subfamily Limoniinae, based on adult morphology.

The biological information of Lechriini is given only in $T$. (C.) munroi: the adults are abundant on the shores of a river, normally resting on dry leaves or soil surface in shady places [Gavryushin, 2016]. Immature stages of the tribe are unknown. The phylogenetic position of the tribe in Limoniidae, and the morphological characters of the tribe haven't been mentioned.

In Japan, there is no record of the species of Lechriini [Nakamura, 2014]. In this paper, Lechriini are newly recorded and three new species of the tribe are described from Japan. The morphological characters of Lechriini are mentioned and a key to the Japanese species is provided.

\section{Materials and Methods}

The specimens used in this study were collected by insect nets or malaise traps (MT) and are preserved in the Biosystematic Laboratory, Kyushu University, Japan (BLKU). Male terminalia were cut off and cleared 
by heating in a solution of $10 \% \mathrm{KOH}$ for several minutes, then rinsed in a solution of $70 \%$ ethanol $+3 \%$ acetic acid for neutralization. The cleared terminalia were preserved in genitalia tubes filled with glycerol and the tubes were pinned below the labels of dried specimens. Species descriptions were based on observations of pinned specimens using ZEISS Stemi 305 or LEICA MZ7.5 stereomicroscopes. Terminology for general description mainly follows Cumming and Wood [2017] and that for male terminalia mainly refers to Ribeiro [2008].

\section{Lechriini}

Diagnosis. Antenna 16-segmented; rostrum much shorter than remainder of head; prescutum with prescutal pit distinct and large, tuberculate pit very close to anterior margin of prescutum; wing with $\mathrm{R}_{1}$ usually indistinct or obsolete at tip before reaching at $\mathrm{C}$, erect or strongly bent anteriorly after joining crossvein $r-r ; R_{2+3}$ forked into $R_{2}$ and $R_{3}$; crossvein r-r oblique or curved, anterior end situated proximal to posterior end, at least proximal part almost or somewhat parallel to $\mathrm{R}_{1}$ (excluding tip of $\mathrm{R}_{1}$ ); posterior end of crossvein r-r joining $\mathrm{R}_{2+3}$ or $\mathrm{R}_{2} ; \mathrm{M}_{1+2}$ not forked; legs with mid and hind coxae close together; tibial spurs present or absent; male terminalia with segment 9 contiguous; interbase present, with bridge joining each interbase; dorsal paramere articulated with interbase.

Remarks. The characters of the crossvein r-r, tip of $\mathrm{R}_{1}$, and $\mathrm{M}_{1+2}$ are very similar to those of the tribe Limoniini, but three branches of Rs reaching wing margin are not present in Limoniini. The structure of the male terminalia resembles that of the tribe Elephantomyiini and some genera of Limnophilinae (e.g. Hexatoma Latreille, 1809) in terms of presence of bridge of interbase. The combination of these characters of wing venation and male terminalia is considered to be unique as tribe in Limoniidae. Alexander [1964] used the long appendage on vertex (corniculus) as a character of the tribe Lechrini in the key to subfamilies and tribes of Tipulidae (one-family concept) of South Africa. However, this character is only based on an Afrotropical species, Trichoneura (Ceratolimnobia) munroi (Alexander, 1920a). It is the first record of this tribe from Japan.

\section{KeY to JAPANESE SPECIES OF THE TRIBE LeCHRIINI}

1. Eye holoptic; wing with cell $\mathrm{d}$ five times as long as wide (Fig. 2); hind tibiae with tibial spurs . Lechria yamauchii, $\mathbf{s p .} \mathbf{n}$.

- Eye dichoptic; wing with cell d at most twice as long as wide (Figs 10,18); tibiae without tibial spurs. Genus Trichoneura

... 2

2. Vertex with roundish lobe on anterior part (Fig. 8); antepronotum with pronotal appendage; thorax with two whitish longitudinal lines in lateral view

T. (Ceratolimnobia) ishigakiensis, $\mathbf{s p . \mathbf { n } .}$

- Vertex without produced part; antepronotum without appendage; thorax without whitish line

T. (Xipholimnobia) japonica, $\mathbf{s p .} \mathbf{n}$.

\section{Lechria Skuse, 1890}

Lechria Skuse, 1890: 830 (as genus). Type species: Lechria singularis Skuse, 1890 (monotypic).

Diagnosis. Eye completely or nearly holoptic; antepronotum without small membranous areas or pair of small tuber- cles; wing (Fig. 2) with Rs shorter than cell d; crossvein r-m situated at middle of cell $\mathrm{d}$ or distal to it; cell $\mathrm{d}$ at least 3.5 times longer than wide, basal end situated proximal to middle of wing; crossvein m-cu situated near or proximal to middles of wing and cell $\mathrm{d}$; tibial spurs present.

\section{Lechria yamauchii Kato, sp.n. Figs 1-6, 25.}

Material. Holotype, $0^{7}$, JAPAN, Nansei Islands, Kagoshima, Yaku-shima Is., Yakushima-ch, Koseda, Mt. Aiko-dake, plantation forest, Alt. 150 m, 30.VII.2007, T. Yamauchi leg. (MT / BLKU)

Description. Male. Body length: $5.3 \mathrm{~mm}$. Wing length: $7.2 \mathrm{~mm}$. Head grayish brown; eye $3 / 5$ length of head excluding rostrum and mouthparts in lateral view; rostrum ocherous, 2.5 times as long as eye in lateral view; palpus brown, first segment longest, 1.5 times as long as second one; antenna 1.5 times as long as head; scape ocherous, 1.5 times as long as pedicel; pedicel subglobular, slightly longer than wide and wider than scape; flagellum dark brown, flagellomeres oval, reduced in size and length toward apical segment.

Thorax with pronotum ocherous, postpronotum slightly paler; prescutum brown, slightly dark on center, yellowish on anterior $1 / 3$ and lateral side, polished on anterior $1 / 3$; tuberculate pit small; prescutal pit large, curved bacilliform; remainder of mesonotum brown, weakly darkened on center of scutal lobe; pleuron pale dusky yellow, posterior part slightly paler. Wing (Fig. 2) weakly tinged with grayish brown, stigma small, vaguely dark along distal part of $R_{1}$ and proximal part of crossvein r-r; Sc situated about twice length of crossvein r-m distal to level of fork of Rs; tip of $R_{1}$ pale, erect; crossvein $r-r$ parallel to basal part of $R_{1}$ and curved posteriorly at middle, joining $\mathrm{R}_{2+3}$; Rs three times as long as crossvein r-m, almost straight; fork of Rs at level of middle of cell d; $R_{2+3} 2.5$ times as long as $R_{2}$ and 1.5 times as $R_{3}$; crossvein $\mathrm{r}-\mathrm{m}$ at middle of cell $\mathrm{d}$, anterior end joining Rs before fork; cell d five times as long as wide, inner end situated more than length of crossvein $\mathrm{m}$-cu proximal to level of origin of Rs; crossvein m-cu at basal $1 / 3$ of cell d; $A_{1} 3 / 5$ length of $\mathrm{CuP}$. Legs with coxae and trochanters pale dusky yellow, mid and hind pairs slightly paler; succeeding segments brown, bases of femora weakly paler; segments distal to trochanters missing except in left fore and left hind legs, left fore leg missing distal to tip of tibia; left hind tibiae with two short spurs at tip of ventral side. Halter brown, stem pale dusky yellow.

Abdomen ocherous, tergites weakly and widely dark in middle longitudinal line. Male terminalia (Figs 3-6) with tergite 9 almost straight at caudal margin; gonocoxite gradually narrowed to tip, 1.5 times as long as tergite 9; outer gonostylus blade-shaped, almost straight, half length of gonocoxite, apical $1 / 5$ strongly narrow, acute at tip; inner gonostyus rod-shaped, 1.5 times as long as outer gonostylus, gently curved at middle; interbase long, flat rod-shaped, obtuse at tip, basal part wide and rounded; bridge of interbase with dorsal part squarish; lateral process of parameral sheath long sickle-shaped, weakly curved dorsolaterally, tip ending at level of distal 1/3 of aedeagus; aedeagus long rod-shaped, curved posterodorsally near base, tip extending beyond tip of interbase; ejaculatory apodeme slightly longer than sperm pump, laterally appressed, tongue-shaped in lateral view.

Female. Unknown.

Distribution. Japan (Nansei Islands: Yaku-shima Is.) (Fig. 25).

Etymology. This species is named after the collector, Dr. Takeo Yamauchi. 
Remarks. This species is similar to Lechria longicellula Alexander, 1950, which was described with a single female from India, in terms of body coloration and wing venation, but is differentiated from it by the following characters: scape and pedicel ocherous (dark brown in L. longicellula); prescutum polished on anterior 1/3 (not polished in L. longicellula); wing with cell d slightly shorter than $\mathrm{A}_{1}$ (Fig. 2) (longer than $\mathrm{A}_{1}$ in L. longicellula).
Trichoneura Loew, 1850

Trichoneura Loew, 1850: 36 (as genus).

Type species: Trichoneura vulgaris Loew, 1850 (monotypic) (fossil)

Diagnosis. Eye dichoptic; antepronotum with or without pair of small membranous areas or pair of small tubercles; wing (Figs 10,18) with Rs much longer than cell d; crossvein $\mathrm{r}-\mathrm{m}$ situated at or proximal to middle of cell $\mathrm{d}$; cell $\mathrm{d}$ at most

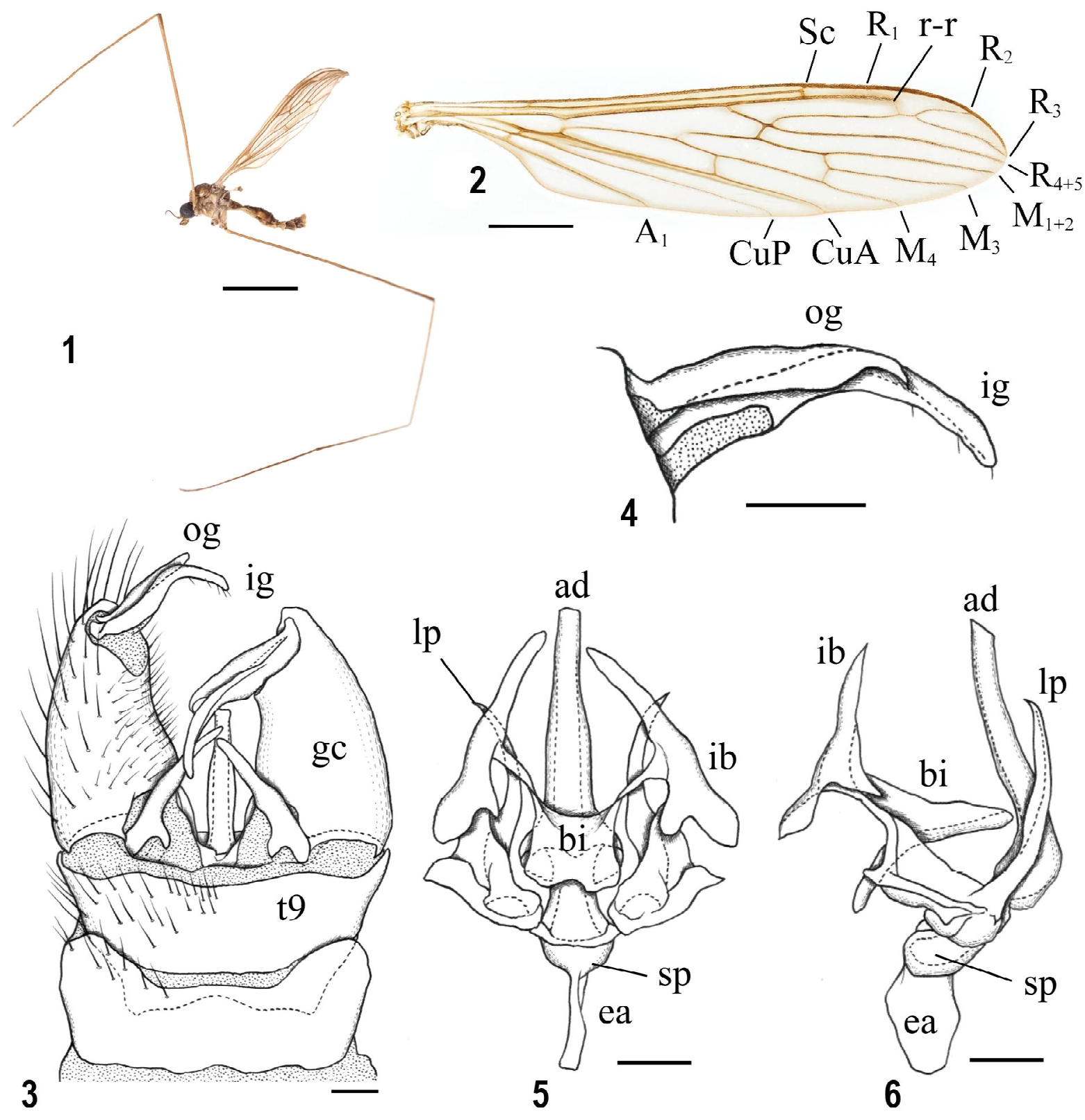

Figs 1-6. Lechria yamauchii sp.n., holotype O': 1 - habitus; 2 - wing; 3 - male terminalia, dorsal view; 4 - gonostyli, ventral view; 5 - internal structure, dorsal view (left $=$ dorsal); 6 - same, lateral view. Abbreviation: ad - aedeagus; bi -bridge of interbase; ea - ejaculatory apodeme; gc - gonocoxite; ig - inner gonostylus; lp - lateral process of parameral sheath; og outer gonostylus; sp - sperm pump; t9 - tergite 9. Scale bar: $1-3 \mathrm{~mm} ; 2-1 \mathrm{~mm} ; 3-6-0.1 \mathrm{~mm}$.

Pис. 1-6. Lechria yamauchii sp.n., голотип О 1 - общий вид; 2 - крымо; 3 - терминали самца, вид сверху; 4 - гоностили, вид снизу; 5 - внутреннее строение, виА сверху (слева = сверху); 6 - то же, виА сбоку. Сокращения: bi - перемычка между интербазами; еа - эякумяторная аподема; gс - гонококсит; ig - внутренний гоностиль; lp - матеральный отросток параметральной оболочки; og - наружный гоностиль; sp - везика; t9 - 9-й тергит. Масштаб: $1-3$ мм; $2-1$ мм; 3-6-0,1 мм. 


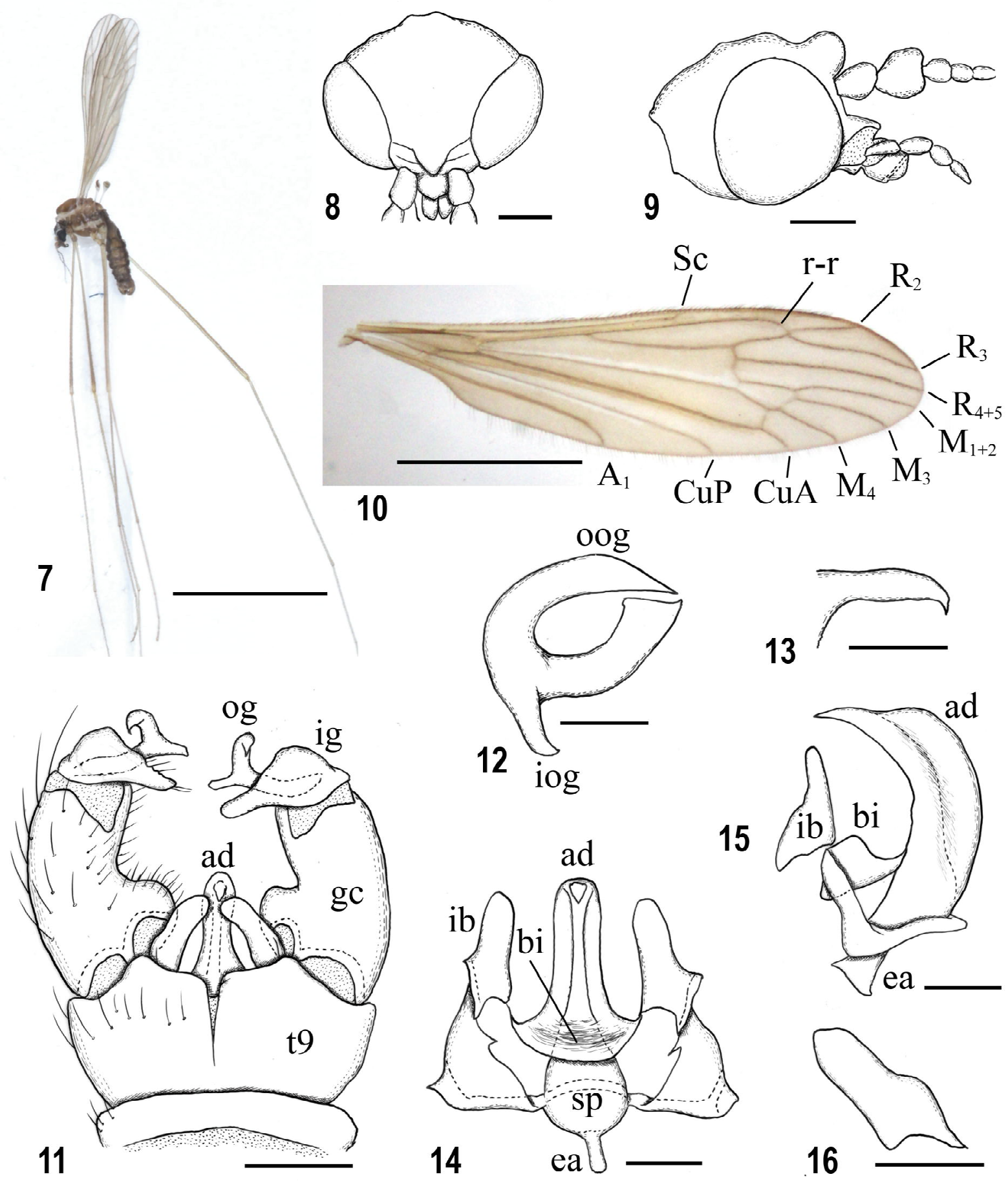

Figs 7-16. Trichoneura (Ceratolimnobia) ishigakiensis sp.n., holotype $0^{7}: 7-$ habitus; 8 - head, dorsal view; 9 - head, lateral view; 10 - wing; 11 - male terminalia, dorsal view; 12 - outer gonostylus, medial view; 13 - inner branch of outer gonostylus; 14 - internal structure, dorsal view (left = dorsal); 15 - same, lateral view; 16 - interbase, dorsal surface. Abbreviation: ad aedeagus; bi - bridge of interbase; ea - ejaculatory apodeme; gc — gonocoxite; ig — inner gonostylus; iog - inner branch of outer gonostylus; og - outer gonostylus; oog - outer branch of outer gonostylus; sp - sperm pump; $\mathrm{t} 9$ - tergite 9 . Scale bar: $7-3 \mathrm{~mm} ; 8-9,11-0.1 \mathrm{~mm} ; 10-1 \mathrm{~mm} ; 12-0.025 \mathrm{~mm} ; 13-16-0.05 \mathrm{~mm}$.

Pис. 7-16. Trichoneura (Ceratolimnobia) ishigakiensis sp.n., голотип О': 7 - внешний вид; 8 - голова, виА сверху; $9-$ голова, вид сбоку; 10 - крыло; 11 - теминалии самџа, вид сверху; 12 - внешний гоностиль, медиальный виА; 13 внутренняя ветвь наружного гоностиля; 14 - внутренняя структура, виА сверху (слева = дорсально); 15 - то же, виА сбоку; 16 - интербаза, верхняя поверхность. Сокрашения: ad - эдеагус; bi - перемычка межку интербазами; еа - эякумяторная аподема; gc - гонококсит; ig - внутренний гоностиль; iog - внутренняя ветвь наружного гоностиля; оg - наружный гоностиль; oog - наружная ветвь наружного гоностимя; sp - везика; t9 - 9-й тергит. Масштаб: 7 - 3 мм; 8-9, 11 - 0,1 мм; $10-1 \mathrm{мм} ; 12-0,025 \mathrm{мм} ; 13-16-0,05 \mathrm{мм}$. 
three times as long as wide, basal end situated distal to middle of wing; crossvein m-cu situated distal to middle of wing, position on cell d variable; tibial spurs present (subgen. Trichoneura) or absent.

\section{Trichoneura (Ceratolimnobia) Alexander, 1920}

Ceratolimnobia Alexander, 1920a: 469 (as genus).

Type species: Ceratolimnobia munroi Alexander, 1920a (original designation).

Diagnosis. Vertex with corniculus or swelling (Fig. 8) near anterior end; antepronotum with pair of fleshy lobes, called pronotal appendage; tibial spurs absent.

Remarks. This subgenus includes only one species in the Afrotropical Region [Oosterbroek, 2020]. Gavryushin [2016] found a peculiar morphological character of Trichoneura (Ceratolimnobia), pronotal apendages, and suggested it represented a useful character for distinguishing from the other subgenera of Trichoneura.

\section{Trichoneura (Ceratolimnobia) ishigakiensis Kato, sp.n. \\ Figs 7-16, 25.}

Material. Holotype, $\mathrm{O}^{7}$, JAPAN, Nansei Islands, Okinawa, Ishigaki Is., Ishigaki-shi, Hirae, south of Nagura Dam, Alt. $80 \mathrm{~m}$, 26.IX.2013, D. Kato leg. (BLKU). Paratypes: JAPAN: [Nansei Islands] $40^{7} \sigma^{\top}$, same data as holotype.

Description. Male. Body length: $2.3-2.4 \mathrm{~mm}$. Wing length: $3.1-3.3 \mathrm{~mm}$. Head dark gray, lighter gray anteriorly, anterior part of vertex produced into rounded lobe, this lobe about 1 / 3 as wide as anterior part of vertex (Fig. 8), and shorter than wide (Fig. 9); eye 3/5 length of head excluding rostrum and mouthparts in lateral view; rostrum brown to dark brown, 1/ 3 length of eye in lateral view; palpus brown to dark brown, basal two segments longest; antenna about twice as long as head, dark brown, first flagellomere yellowish ocherous; scape as long as pedicel; pedicel globular, wider than scape; flagellomeres oval, reduced in size and length toward apical segment.

Thorax with pronotum light ocherous, swollen medially, bearing white tongue-shaped appendage at each lateral end of middle swollen part, about half length of antepronotum, narrowed basally, postpronotum and posterolateral part of antepronotum white; prescutum yellowish brown to brown, lateral margin narrowly white, darker brown on anterior margin and just above white lateral margin; remainder of mesonotum yellowish brown to brown, sometimes weakly darkened on center of scutal lobe; pleuron brown to dark brown, sometimes slightly paler dorsally, with narrow and straight, white stripe running from behind fore coxae to just above hind coxa. Wing (Fig. 10) tinged with brown, stigma absent; Sc situated at level of middle of Rs; tip of $\mathrm{R}_{1}$ obsolete; crossvein $r-r$ somewhat parallel to basal part of $R_{1}$, joining base of $R_{2}$; Rs about six times as long as crossvein $r-m$, almost straight; fork of Rs proximal to level of of cell $\mathrm{d}$ base; $\mathrm{R}_{2+3}$ as long as $\mathrm{R}_{2}$ and half length of $\mathrm{R}_{3}$; crossvein $\mathrm{r}-\mathrm{m}$ joining base of cell $\mathrm{d}$, anterior end joining basal part of $\mathrm{R}_{3}$; cell d 2.5 times as long as wide, inner end situated 2.5 times length of cell d distal to level of origin of Rs; crossvein m-cu at about basal 3/ 4 of cell d; A $3 / 5$ length of CuP. Legs pale dusky yellow, bases of coxae darkened; femora brown to dark brown, bases slightly paler, tips narrowly yellowish; tibiae and tarsi yellowish brown. Halter dark brown, stem pale brown.

Abdomen dark brown. Male terminalia (Figs 11-16) with posterior margin of tergite 9 produced posteriorly at middle part, middle of produced part shallowly and widely con- caved, with deep incision at middle; gonocoxite strongly wide at base, 1.5 times as long as tergite 9; outer gonostylus deeply bifid, outer branch about three times as long as inner one, strongly curved near base, pointed at tip (Fig. 12), inner branch straight, extreme tip curved and pointed (Fig. 13); inner gonostyus long triangular, gradually narrowed toward tip, half length of gonocoxite, obtuse at tip; interbase tongueshaped, about twice as long as wide, distal $2 / 3$ slightly narrower (Fig. 16); bridge of interbase rounded at dorsal margin (Fig. 14); lateral process of parameral sheath absent; aedeagus sickle-shaped in lateral view, curved dorsally on distal part, almost same width in entire length except in apical part, apical part narrowed and directed dorsally, acute at tip (Fig. 15); ejaculatory apodeme shorter than sperm pump, roughly triangular in lateral view.

Female. Unknown.

Distribution. Japan (Nansei Islands: Ishigaki Is.) (Fig. 25).

Etymology. This species is named after the type locality, Ishigaki Island.

Remarks. This species is similar to an Indonesian species, T. (T.) umbrosa Alexander, 1948 and an Indian one, $T$. (X.) umbripennis Alexander, 1949 in terms of colorations, but is differentiated from them by the following characters: anterior part of vertex produced anteriorly into rounded lobe (Figs 8-9) (not produced in the two species); femora brown to dark brown with narrowly yellowish tips (without yellowish tips in the two species); tibial spur absent (present in T. umbrosa).

\section{Trichoneura (Xipholimnobia) Alexander, 1921}

Xipholimnobia Alexander, 1921: 318 (as genus).

Type species: Xipholimnobia terebrina Alexander, 1921 (original designation).

Diagnosis. Vertex smooth, without corniculus or swelling near anterior end; antepronotum with pair of small membranous areas and without pronotal appendage; tibial spurs absent.

Remarks. This subgenus includes 8 species in the world ( 2 in the Afrotropical, 6 in the Oriental Regions) [Oosterbroek, 2020].

\section{Trichoneura (Xipholimnobia) japonica Kato, sp.n.} Figs $17-24,26$

Material. Holotype, $\bigcirc^{\top}$, JAPAN, Nansei Islands, Okinawa, Ishigaki Is., Ishigaki-shi, Ishigaki, Mt. Banna-dake, Alt. $100 \mathrm{~m}$, 13.V.2016, D. Kato leg. (BLKU). Paratypes: JAPAN: [Nansei Islands] $90^{\top} \sigma^{\top}$, same data as holotype; 1+, Okinawa, Ishigaki Is., Ishigaki-shi, Hirae, south of Nagura Dam, Alt. $80 \mathrm{~m}$, 27.IX.2013, D. Kato leg. (BLKU); $40^{7} \mathrm{O}^{7} 2$ 290, Okinawa, Iriomote Is., Taketomi-ch, Komi, Maira-gawa River, Alt. 20 m, 17.V.2016, D. Kato leg. (BLKU); $10^{\top} 1$, same data as previous except 7.VIII.2016; $10 \sigma^{2} \sigma^{2}$, Okinawa, Iriomote Is., Taketomi-ch, Haeminaka-Haemi, Alt. 170-220 m, 19.V.2016, D. Kato leg. (BLKU); $10^{7}$, same data as previous except Alt. $150-220 \mathrm{~m}$, 6.VIII.2016; 1잉. Okinawa, Iriomote Is., Taketomi-ch, Iriomote, near Urauchi-gawa River, Alt. 30 m, D. Kato leg. (BLKU).

Description. Male. Body length: $2.2-2.7 \mathrm{~mm}$. Wing length: $3.4-4.0 \mathrm{~mm}$. Head dark grayish brown, anterior part of vertex with squarish and more brownish spot, anterior margins of vertex and eye light gray; eye 3/5 length of head excluding rostrum and mouthparts; rostrum brown to dark brown, $1 / 2$ length of eye in lateral view; palpus brown to dark brown, terminal segment longest, slightly longer than first and second ones; antenna 2.5-3 times as long as head, dark brown; scape 1.5 times as long as pedicel; pedicel subglobular, slight- 


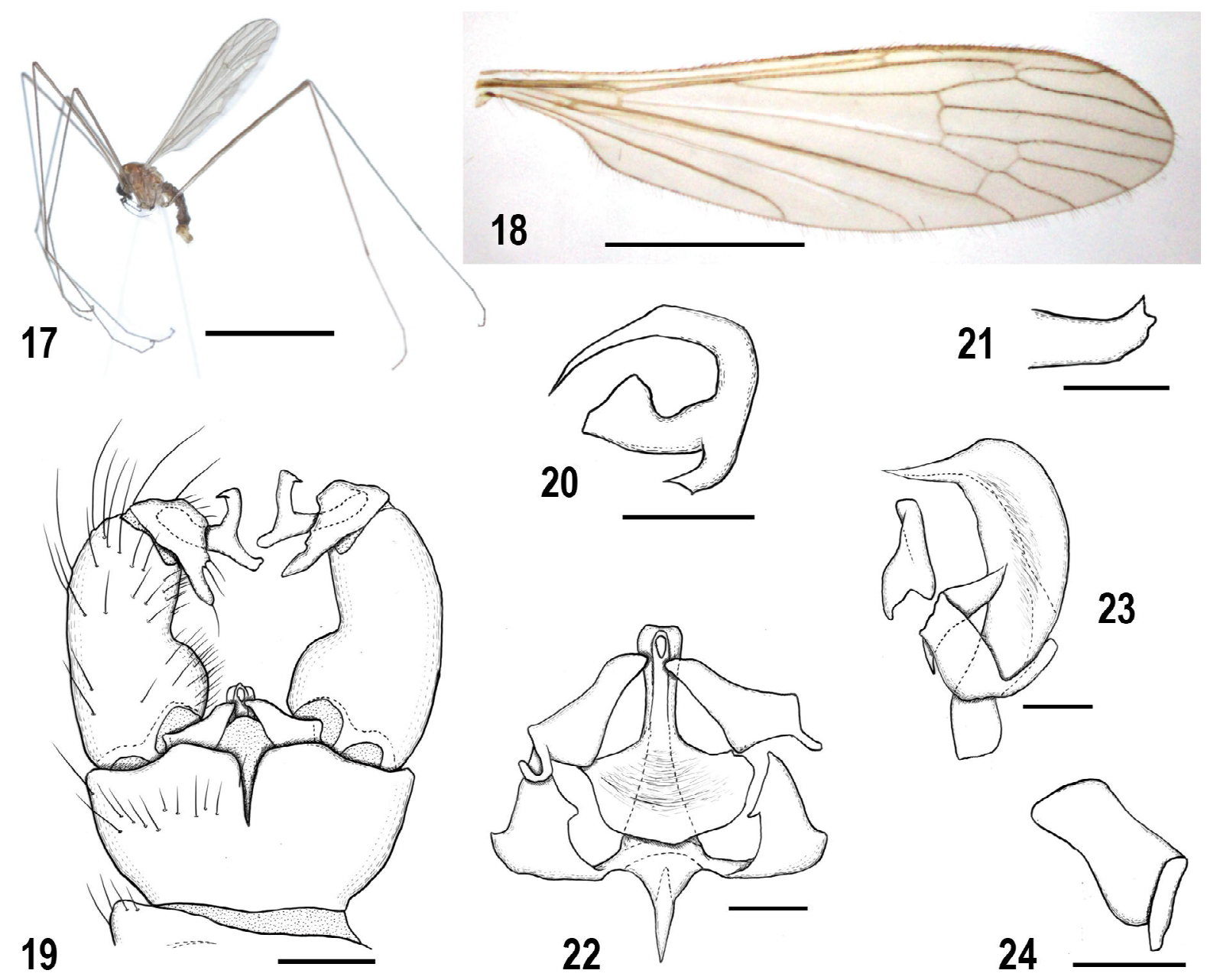

Figs 17-24. Trichoneura (Xipholimnobia) japonica sp.n., paratype $O^{7}: 17$ - habitus; 18 - wing; 19 - male terminalia, dorsal view; 20 - outer gonostylus, medial view; 21 - inner branch of outer gonostylus; 22 - internal structure, dorsal view; $23-$ same, lateral view; $24-$ interbase, dorsal surface. Scale bar: $17-3 \mathrm{~mm} ; 18-1 \mathrm{~mm} ; 19-0.1 \mathrm{~mm} ; 20-0.025 \mathrm{~mm} ; 21-24-$ $0.05 \mathrm{~mm}$.

Рис. 17-24. Trichoneura (Xipholimnobia) japonica sp.n., паратип О’: 17 - общий вид; 18 - крыло; 19 - терминали самца, виА сверху; 20 - внешний гоностиль, медиальный виА; 21 - внутренняя ветвь наружного гоностиля; 22 внутреннее строение, виА сверху; 23 - то же, виА сбоку; $24-$ интербаза, дорсальная поверхность. Масштаб: $17-3$ мм; $18-1 ; 19-0,1$ мм; $20-0,025$ мм; 21-24-0,05 мм.

ly longer than wide and slightly wider than scape; flagellomeres oval, reduced in size and length toward apical segment.

Thorax with antepronotum dark brown, sometimes yellowish laterally, postpronotum brown to yellowish brown; prescutum yellowish brown to brown, slightly paler at lateral margin; remainder of mesonotum yellowish brown to brown; pleuron pale yellowish ocherous to brown, sparsely dusted with whitish gray. Wing (Fig. 18) tinged with brown, stigma absent; Sc situated at level of distal 2/3 of Rs; tip of R obsolete or appearing as short spur; crossvein r-r almost parallel to basal part of $R_{1}$, joining base of $R_{2}$; Rs about seven times as long as crossvein r-m, almost straight; fork of Rs slightly proximal to level of of cell $\mathrm{d}$ base; $\mathrm{R}_{2+3}$ as long as $\mathrm{R}_{2}$ and half length of $\mathrm{R}_{3}$; crossvein $\mathrm{r}-\mathrm{m}$ joining base of cell $\mathrm{d}$, anterior end joining basal part of $\mathrm{R}_{3}$; cell d 2.5 times as long as wide, inner end situated 2.5 times length of cell d distal to level of origin of Rs; crossvein m-cu at about basal 3/4 of cell d; A 3/5 length of CuP. Legs pale dusky yellow to pale brown, sometimes trochanters slightly darker; remainder of legs dark brown, bases of femora narrowly and weakly yellow. Halter dark brown, base of stem yellow.

Abdomen brown to dark brown, sternites paler. Male terminalia (Figs 19-24) pale yellowish ocherous; tergite 9 with posterior margin produced posteriorly on middle part, middle of produced part slightly and widely concaved, with deep incision at middle; gonocoxite strongly wide at base, 1.5 times as long as tergite 9; outer gonostylus deeply bifid, outer branch about four times as long as inner one, strongly curved near base, distal $1 / 2$ very narrow, pointed at tip (Fig. $20)$, inner branch curved at middle, apical margin with several small spines (Fig. 21); inner gonostyus roughly long triangular, gradually narrowed toward tip, half length of gonocoxite, obtuse at tip; interbase roughly tongue-shaped, about twice as long as wide, middle part slightly constricted, inner side slightly longer (Fig. 24); bridge of interbase rounded at dorsal margin (Fig. 22); lateral process of parameral sheath absent; aedeagus sickle-shaped in lateral view, base narrower than distal part before tip, apical part nar- 


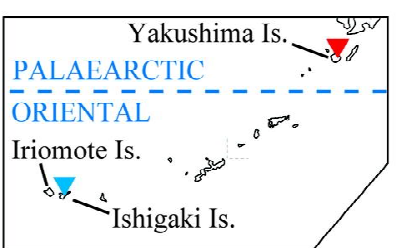

Nansei Islands

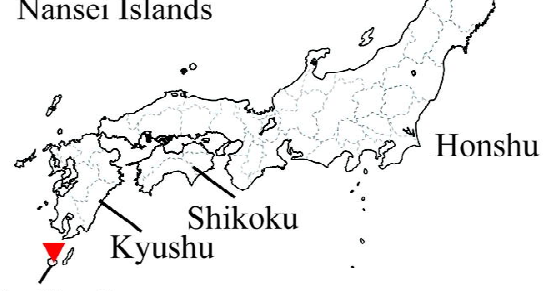

Yakushima Is.
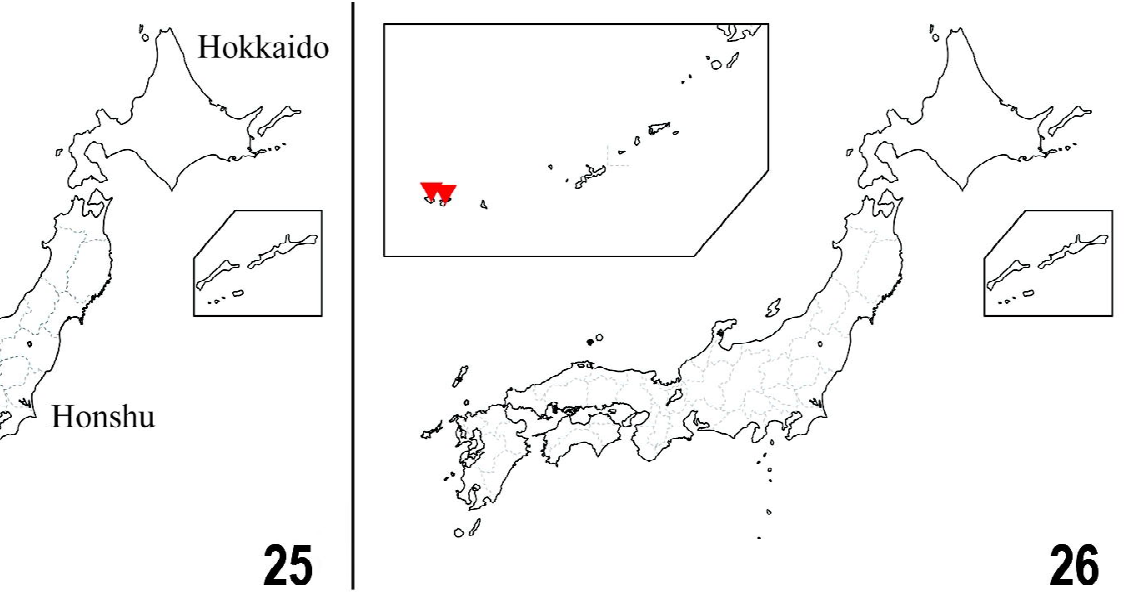

Figs. 25-26. Distributions of Japanese Lechriini. 25 - Lechria yamauchii sp.n. (red) and Trichoneura (Ceratolimnobia) ishigakiensis sp.n. (blue); 26 - T. (Xipholimnobia) japonica sp.n.

Рис. 25-26. Распространение Lechriini в Японии. 25 - Lechria yamauchii sp.n. (красный треугольник) и Trichoneura (Ceratolimnobia) ishigakiensis sp.n. (синий треугольник); 26 - T. (Xipholimnobia) japonica sp.n.

rowed and directed dorsally, acute at tip (Fig. 23); ejaculatory apodeme shorter than sperm pump, roughly square in lateral view.

Female. Body length: 3.4-3.6 mm. Wing length: 3.5-3.9 $\mathrm{mm}$. Almost same as male. Ovipositor mainly dusky yellow; cercus and hypogynial valve reddish yellow and long, cercus much longer than united length of tergites 8-10.

Distribution. Japan (Nansei Islands: Ishigaki and Iriomote Is.) (Fig. 26).

Etymology. This species is considered to be the most common one in Japanese Lechriini. Thus, this new species is named after Japan as a representative of the Japanese species.

Remarks. This species is similar to an Indian species, T. (X.) madrasensis Alexander, 1970, but is differentiated from it by the following characters: outer gonostylus with outer branch about four times as long as inner one, strongly curved near base and narrowed on distal $1 / 2$, acute at tip (Fig. 20) (outer branch much shorter and rounded at tip in T. madrasensis); inner gonostyus long triangular, gradually narrowed toward tip (Fig. 19) (slender rod-shaped, almost same width in whole length in T. madrasensis).

\section{Acknowledgement}

We are thankful to Dr. Jon Gelhaus (the Academy of Natural Science of Drexel University, Philadelphia, USA) for helping us examine specimens in USNM and to Drs. Floyd Shockley and Torsten Dikow (USNM) for allowing examine their specimens. We would like to thank Dr. Takeo Yamauchi (Obihiro University of Agriculture and Veterinary Medicine) for giving specimens of the new species.

\section{References}

Alexander C.P. 1920a. New or little-known Tipulidae (Diptera). III. Ethiopian species // Annals and Magazine of Natural History. (9). Vol.5. P.465-472.

Alexander C.P. 1920b. New or little-known Australian craneflies (Tipulidae, Diptera) // Proceedings of the Royal Society of Queensland. Vol.32. P.92-109.
Alexander C.P. 1920c. New or little-known crane-flies in the Queensland museum (Tipulidae, Diptera) // Memoirs of the Queensland Museum. Vol.7. P.52-63.

Alexander C.P. 1921. New or little-known Tipulidae (Diptera). IV. Ethiopian species // Annals and Magazine of Natural History (9). Vol.7. P.305-322.

Alexander C.P. 1927. Fauna Sumatrensis (Beitrag Nr. 39). Superfamily Tipuloidea (Dipt.). I // Supplementa Entomologica. Vol.15. P.90-102.

Alexander C.P. 1934. New or little-known Tipulidae from the Philippines (Diptera). XVII // Philippine Journal of Science. Vol.53. P.429-468.

Alexander C.P. 1948. New or little-known Tipulidae (Diptera). LXXVIII. Oriental-Australasian species // Annals and Magazine of Natural History (11). Vol.14. P.256-280.

Alexander C.P. 1949. New or little-known Tipulidae (Diptera). LXXXII. Oriental-Australasian species // Annals and Magazine of Natural History (12). Vol.1. P.639-663.

Alexander C.P. 1950. New or little-known Tipulidae (Diptera). LXXXVI. Oriental-Australasian species // Annals and Magazine of Natural History (12). Vol.3. P.301-324.

Alexander C.P. 1964. Diptera (Nematocera): Tanyderidae, Ptychopteridae, Tipulidae // South African Animal Life. Vol.10. P. 229-441.

Alexander C.P. 1970. New and little-known Indian craneflies (Diptera: Tipulidae). III // Oriental Insects. Vol.4. P.77-88.

Brunetti E. 1911. Revision of the Oriental Tipulidae with descriptions of new species // Records of the Indian Museum. Vol.6. P. 231-314.

Brunetti E. 1918. Revision of the Oriental Tipulidae with descriptions of new species, Part 2 // Records of the Indian Museum. Vol.15. P.255-344

Cumming J.F., Wood D.M. 2017. Adult morphology and terminology // Kirk-Spriggs A.H., Sinclair B.J. (Eds). Manual of Afrotropical Diptera. Volume 1. Introductory chapters and keys to Diptera families. Suricata. Vol.4. South African National Biodiversity Institute. Pretoria. P.89-133.

Gavryushin D.I. 2016. Six new species of limoniid flies (Diptera: Limoniidae) from Tanzania and notes on other species new to the countrys fauna // Russian Entomological Journal. Vol.25: 273-286.

Kania I. 2015. Subfamily Limoniinae Speiser, 1909 (Diptera: Limoniidae) from Baltic amber (Eocene): the genus Trichoneura Loew, 1850 // Acta Zoologica Cracoviensis. Vol.58. P.1-19. 
Latreille P.A. 1809. Genera crustaceorum et insectorum secumdum ordinem naturalem in familias disposita, iconibus exemplisque plurimis explicata. Tomus Quartus et Ultimus // A. Koenig, Parisiis et Argentorati [= Paris and Strasbourg]. Vol.4. P.1-399.

Loew H. 1850. Uber den Bernstein und die Bernsteinfauna // Programm K. Realschule zu Meseritz. Vol.1850. P.344.

Meijere J.C.H. de 1911. Studien uber Sudostasiatische Dipteren, V. Ostindische Tipulidae // Tijdschrift voor Entomologie. Vol.54. P.21-79.

Nakamura T. 2014. Family Limoniidae // Nakamura T., Saigusa T., Suwa M. (Eds): Catalogue of the Insects of Japan. Vol.8. Diptera, Part 1. Nematocera-Brachycera Aschiza. Touka Shobo. Fukuoka. P. 9-53.

Oosterbroek P. 2020. Catalogue of the Craneflies of the World (Diptera, Tipuloidea: Pediciidae, Limoniidae,
Cylindrotomidae, Tipulidae). Version 20 May 2020. Online version at https://ccw.naturalis.nl/index.php.

Ribeiro G.C. 2008. Phylogeny of the Limnophilinae (Limoniidae) and early evolution of the Tipulomorpha (Diptera) // Invertebrate Systematics. Vol.22. 627-694.

Skuse F.A.A. 1890. Diptera of Australia, Part 7. The Tipulidae brevipalpi // Proceedings of the Linnaean Society of New South Wales. 2. Vol.4. P.757-892.

Stary J. 1992. Phylogeny and classification of Tipulomorpha, with special emphasis on the family Limoniidae // Acta Zoologica Cracoviensia. Vol.35. P.11-36.

Tjeder B. 1981. Limoniidae, tribe Toxorhinini (Diptera: Tipulidae) from Senegal and the Gambia // Entomologica Scandinavica. Vol.12. P.39-47.

Wesche W. 1910. On the new tipulid subfamily Ceratocheilinae // Journal of the Linnean Society of London, Zoology. Vol.30. P.355-360.

Поступила в редакцию 5.10.2020 